\title{
System of Regular Remedial Measures in the Administrative Procedure in the Czech Republic and Other Countries of the So-Called V4*
}

\author{
Lukáš Potešil ${ }^{* *}$
}

\begin{abstract}
* This paper was created as a result of the project 'Postdoc I' (reg. No. CZ.1.07/2.3.00/30.0009). The project is co-financed by the European Social Fund and the state budget of the Czech Republic.

** JUDr. Lukáš Potešil, PhD., senior lecturer, Department of Administrative Sciences and Administrative Law, Faculty of Law, Masaryk University in Brno. His main fields of research are: administrative offences, administrative responsibility, regulation of administrative procedures, remedies in administrative procedures. (e-mail: lukas.potesil@law.muni.cz)
\end{abstract}

Abstract: This article focuses on the system of standard (ordinary) remedial measures used in the administrative procedure that can be found in the Administrative Procedure Acts of so called Visegrad Four (Central European) countries. Mentioned is not only the national legislation but also European impact in this sphere and connecting roots. It can be found some problems that are typical for Visegrad Four countries like 'remonstrance'. This paper tries to show possible ways to solve such problems and to emphasize that there is still number of national specifics which can be found. These can be understood as 'inspirational designs', whether positive or negative.

Keywords: administrative procedure; administrative procedure act; appeal; remonstrance; judicial review

\section{Introduction}

Generally speaking, regular remedial measures are sought by parties to the administrative procedure to protect their (substantive or procedural) rights. These measures are sought to contest (meritorious or procedural) decisions of the firstinstance administrative body, which have not yet come into legal force. So the authority over the respective matter is transferred to the superior/higher administrative body.

This contribution stems from the individual description and the subsequent overall comparison of the examined issue in the countries of the so-called Visegrad Four (hereinafter 'V4') and focuses solely on comparing the general legislations contained in the rules of administrative procedure of these states. It deals neither with the specific regular remedial measures that may apply in particular cases, such as the execution, or within the so-called special administrative procedure pursuant to the special law 1 nor with the detailed description of specific legislations and institutes.

This contribution tries to answer a question as to whether the institutes and systems of regular remedial measures in V4 countries, which have similar backgrounds and closely cooperate with one another, are similar or whether they differ in some respects. In relation to this, the contribution also refers to the so-called Europeanisation tendencies given by 'European' requirements that should be reflected on the national legislations concerned.

\section{The so-called V4 group}

At first, I consider as appropriate to succinctly delineate what the term 'V4 group/states' means and why this article deals with the system of regular remedial measures contained in the rules of administrative procedure of these countries.

The so-called V4 is a political (rather than legal) group of four Central European states, including the today's Czech Republic, Slovak Republic, Republic of Poland, and Hungary. Rather than a (classical) international organization, it is a regional group the beginning of which can be dated back to 15 February 1991 when the Presidents of the stated countries (at the time of the then Czechoslovak Republic) signed a declaration of cooperation towards European integration and building of democratic legal states. Their mutual cooperation stemming from this platform 2 did not let up despite the common accession to the European Union on 1 May 2004. It can even be said that the significance and importance of this group have been strengthened upon the accession to the European Union and the V4-based cooperation still continues in various spheres.

The reason why my contribution is devoted to selected institutes and legislative systems of these countries is their social, historical, geographical, language, cultural and political closeness confirmed, at the institutional level, by the existence of V4 Group. The stated countries declared that they had been and were part of one civilization sharing the same values and that V4 group's objective was to preserve, and, concurrently, contribute to strengthening, their mutual cooperation. 
The stated introduction and V4's proclamations may tend to infer relationship amongst the individual legislations. After all, they are members of not only the European Union but also the Council of Europe and are governed by similar principles or requirements (see below). However, it is not that easy. They do show certain similarities, but there are also differences.

The mentioned relationship amongst the legislations is given or even strengthened by their common history (and the same legal order), for Slovakia and Hungary until 1918 and for Slovakia and the Czech Republic from 1918 to 1992. Moreover, in case of the Czech and Slovak Republics, including Poland, a role is also played by the similarity of languages. Hungary is singled out when it comes to the language, but not when it comes to the transition to democracy and its values. All V4 states belong to a group of post-socialist countries, facing similar challenges, tasks and problems. These include, among other things, the establishment of an efficient and generally understandable system of (regular) remedial measures through which individuals could contest administrative bodies' decisions handed down within the administrative procedure.

\section{V4 Countries' administrative orders}

The contribution focuses on the so-called regular remedial measures sought within the administrative procedure and on the systems of administrative procedure rules of V4 states. For the purposes of this contribution it is crucial, in particular, that all V4 states' administrative procedure rules are reduced to, and have the force of, laws and their contents and focus are similar. This fact facilitates the comparative approach and underlines its sense and purpose.

Regarding the system of regular remedial measures contained in the administrative procedure rules, it is necessary to first briefly state several notes relating to the term 'administrative procedure rules' and, subsequently, to deal with the concept of administrative procedure and regular remedial measures.

Laws usually identified as 'administrative procedure rules' exist not only in central Europe but also in other parts of the European continent. 3 Nevertheless, especially Central Europe is typical of the existence of administrative procedure rules. 4 In terms of history, the administrative procedure rules have had a relatively long tradition in central Europe. 5

The term 'administrative procedure rules' means, (not only) in the V4 countries, the general legal regulation (lex generalis) of various procedures applied by public administration through bodies $\underline{6}$ called, in theory, as 'administrative bodies'. 7 The subject of the legislation contained in the Administrative Procedure Code is then the public administration activity of these bodies. $\underline{8}$

Administrative bodies and administrative procedures are regulated, similar to (civil, criminal or administrative) courts, by Codes and Rules.2 For this reason, administrative procedure rules are usually referred to as codes of public administration (activity). 10

The oldest administrative procedure codes could be found in Poland (1960), followed by the Slovak Republic (1967). However, in both cases, the existing administrative procedure rules differ from the then legislation. After the substantial changes in 1989 and in relation to their incorporation in the European structures (Council of Europe and European Union), these states have preserved their administrative procedure rules, with more or less significant interventions. On the other imaginary side are the 'new' administrative procedure rules of the Czech Republic and Hungary, both adopted in 2004. In these cases, the legislature decided to adopt a completely new legislation to meet the Europeanization requirements. Poland and Slovakia preserved the original form of legislation, save for certain changes. Moreover, the Polish and Slovak legislations seem to be more stable. The legislation of Polish and Slovak administrative procedure rules is more succinct when it comes to the quantity and, in particular, the length of provisions. The fact that the last Section of the Polish Administrative Procedure Code is 269, while that of the Slovak Administrative Procedure Code is 85 (the actual number of provisions is lower because in both cases, it also includes the cancelled provisions) changes nothing. Conversely, the Czech and Hungarian Administrative Procedure Codes seem to be much more detailed at first sight and are more extensive. The Czech Administrative Procedure Code has 184 Sections that are further broken down into very detailed paragraphs and subparagraphs. This makes the Administrative Procedure Code more extensive although, in fact, it contains fewer provisions than the Polish Administrative Procedure Code. The Hungarian Administrative Procedure Code has 189 Sections that are very detailed and broken down. It may be disputable as to for whom the brevity or, conversely, the extensiveness of legislation constitutes an advantage. In any case, the comparison of the individual Administrative Procedure Codes tends to indicate adoption of the so-called case-by-case approach. The legislation, however general it should be, tries to cover solutions to all possible situations and remember various types of cases. 
Thus, all V4 countries have their rules of administrative procedure and understand them within the intentions stated above. For this reason, we can state that the administrative procedure rules of V4 countries are comparable as to their focus. However, the individual administrative procedure rules may differ and, in fact, they do differ, in particular, when it comes to the processes regulated by them. This is given by the different scope of their applicability.

The thing is that public administration is performed by means of various legal measures (forms). In fact, this variety is caused by a wide range and by the specificity of the sphere of administered social relationships. The objectives and tasks of public administration of the $21^{\text {st }}$ century do not allow being fulfilled in a single form, similar to the legislative (where the form of activity is a normative legal act - 'law') or judicial (where the form of activity is the act of applying the law 'decision') power. The complexity of the domains administered by public administration and the high number of addressees of such activity requires a high number of the applied forms. Furthermore, public administration is typical of combining normative and application activities predetermining the diversity of possible forms. Comparing the administrative procedure rules and the scopes of their applicability, we can arrive at the following general findings further demonstrated by the table below. $\underline{11}$

\begin{tabular}{|c|c|c|c|}
\hline Country & Year of Adoption & Number of Provisions (including cancelled) & Contents/Scope of Applicability \\
\hline Poland & 1960 & 269 & $\begin{array}{l}\text { 1. administrative procedure } \\
\text { 2. other acts (certificates) }\end{array}$ \\
\hline Slovak Republic & 1967 & 85 & 1. administrative procedure $\underline{12}$ \\
\hline Czech Republic & 2004 & 184 & $\begin{array}{l}\text { 1. administrative procedure } \\
\text { 2. other acts (certificates) } \\
\text { 3. public contracts } \\
\text { 4. measure of a general nature }\end{array}$ \\
\hline Hungary & 2004 & 189 & $\begin{array}{l}\text { 1. administrative procedure } \\
\text { 2. other acts (certificates) } \\
\text { 3. administrative contracts }\end{array}$ \\
\hline
\end{tabular}

Concurrently, it is crucial that these rules predominantly regulate the so-called administrative procedure. It is a traditional process within which the administrative bodies decide on the rights and legally protected interests and obligations of the parties to such procedure and the result of which is a decision on these rights and obligations, as can be deduced directly from the texts of the legislations (Administrative Procedure Codes) of V 4 countries. 13

Since the administrative procedure rules of V4 countries are similar in essence, even the issue of regular remedial measures is understood similarly. Therefore, a regular remedial measure is, generally speaking, a means available to the party to administrative procedure (the party to administrative procedure is entitled to it) and contesting, within the given time-limit, a fist-instance administrative decision that has not yet come into legal force. Thus, the authority to pass a decision on the remedial measure and review the whole matter is transferred to the superior administrative body (the socalled effect of devolution). 14 The above-stated further shows that the legislations contained in the Polish and Slovak Administrative Procedure Codes are, unlike those of the Czech and Hungarian Administrative Procedure Codes, rather succinct.

However, before describing the individual administrative procedure rules and the system of regular remedial measures contained in them, I consider it useful to deal with the common European roots and requirements leading to the legislations concerned being similar in essence.

\section{Administrative procedure and regular remedial measures from European perspective}

It would be a mistake to believe that the examined legislations are free of European influences and fall solely within the competence of the national legislature. However, a role is also played by the legal tradition and, to certain extent, by the insistence on the system and legal regulation of regular remedial measures, which may evoke problems and criticism (in particular, in relation to the existence of the remonstrance as stated below). We can understand the mentioned European requirements, in particular, as value-based solutions that should be contained in the legislation. Concurrently, they constitute the minimal procedural standards (de minimis) which the national legislation should fulfil and reflect on. 
The issue of the right to (regular) remedial measures is dealt with by numerous documents of the so-called European Administrative Law, the creator of which is, in particular, the international organization Council of Europe. The individual documents 15 issued by the bodies of the Council of Europe state that there should be a system of the regular remedial measures of which the addressees of decisions handed down within the administrative procedure should be duly notified. The anchorage of this procedural law is then reflected on other soft-law documents of the Council of Europe.16 These documents require that the regular remedial measures available within the administrative procedure are first exhausted in vain before the court is involved and court protection is awarded.

The stated facts lead to a partial conclusion that the requirement for existence of regular remedial measures is part of the so-called European Administrative Area, that is, an area of common values and principles that influence soft law of the Council of Europe. The existence or the previous exhaustion of regular remedial measures is considered as the basis for asserting the right to protection from procedures carried out by administrative bodies. Regular remedial measures are understood as the (necessary) pre-level for granting court protection, as required by Article 6(1) of the European Convention for the Protection of Human Rights and Fundamental Freedoms. Even thanks to this, the issue of regular remedial measures gains new perspective.

At the level of the European Union as such (within the so-called direct Union administration), numerous procedures that could be subordinated to administrative procedures can be found. Their specificity lies in such procedure not being carried out by national administrative bodies, but directly by the Union bodies or institutions 17 , which is obvious, particularly, in relation to the direct decision-making activity of the so-called independent agencies. 18

While a unification mechanism for conducting administrative procedure, represented by the administrative procedure rules, exists at the national level of implementing the Union law, it is absent at the Union level. No matter how Article 41 of the Charter of Fundamental Rights of the EU, including the right to good governance, applies to the direct Union level, it contains no right to seek regular remedial measures although it should contain such right. After all, the right to good governance, as also ensues from the stated documents of the Council of Europe, undoubtedly includes the right to seek regular remedial measures. The European Union tries to compensate for this deficit by adopting EU administrative procedure rules.19

The stated documents and requirements under the so-called European Administrative Law are typical of having the so-called Europeanization effect (top-down approach) and influence national legislations of the individual European states. For this reason, it can be stated that the existence of a system of regular remedial measures and the requirement for their previous application before court protection is granted as results of the Europeanization. Concurrently, the Europeanization affects the European Union itself since the contemplations about adopting EU administrative procedure rules are reflected on the individual Member States (bottom-up approach).

\section{Poland and administrative procedure code}

The Polish Administrative Procedure Code is the oldest of the V4 countries. It was adopted in 1960 and has been amended more than 20 times since then. $\underline{20}$ Its abbreviation established in the Polish environment is ' $K P A$ '. In the Central European area (including V4 area), it represents other significant source of inspiration for other Administrative Procedure Codes after the German ' $V w V f G$. Its contents and system, even within the scope of remedial measures, are close to the Czech and Slovak Administrative Procedure Codes. The scope of its applicability has already been briefly delineated above.

The legislation and the system of regular remedial measures in Poland stem from the constitutional principle of a twoinstance procedure, within which rights and obligations are determined. Section 78 of the Polish Constitution introduces a constitutional right to seek remedial measures. The principle of a two-instance procedure at the statutory level and in the sphere of public administration is specified in Section 15 of KPA, pursuant to which 'the administrative procedure shall have two tiers'. Exceptions to this rule as stipulated by the laws are admissible.21

The stated general provisions are specifically related to Sections 127 and 141 of KPA that define the regular remedial measures available to the parties.22 These remedial measures are an appeal (Section 127(1) of KPA - odwolanie) and a complaint (Section 141(1) of KPA - zazalenia). The appeal is further associated with the so-called auto-remedy. The appeal differs from the complaint by being aimed against a decision on the merits, while the complaint is filed against a decision of a procedural nature and only in cases when so specifically stipulated by the Code. Other difference lies in the presence of the effect of suspension, which applies in case of the appeal, but is missing when it comes to the complaint. The filing time-limits differ too. The time-limit for filing an appeal is 14 days and that for filing a complaint is 7 days. Otherwise, Section 144 of KPA refers to appeal-related laws being applicable to the complaint. 
Furthermore, the Polish legislation contains a specific remedial measure that is similar to the remonstrance recognized by the Czech and Slovak laws (see below). Pursuant to Section 127(3) of KPA, it concerns an application for renewed procedure (wniosek o ponowe rozpatrzenie sprawy) in cases when a minister or a self-governing collegial body has passed a first-instance decision. In these cases, it is not possible to apply the standard regular remedial measure, including its devolution effect, since the stated bodies have no superior authority over themselves that would conduct such procedure. Despite this, the stated institute is subject to the rules pertaining to the appeal and the appellate procedure. This legislation raises numerous questions in Polish theory 23 and is sometimes referred to as internal remedy. Its essence lies in the review of an administrative decision by the same authority. 24

\section{Slovak republic and Act No. 71/1967 Coll., on the Administrative Procedure Code}

Regarding the Slovak Administrative Procedure Code, it needs to be mentioned that it concerns the original Czechoslovak (federal) Administrative Procedure Code that was common to the Czech Republic and Slovakia until 31 December 1992. Nevertheless, this Administrative Procedure Code applied, though in its amended form, in both countries even after they had separated. While a completely new legislation was adopted by the Czech Republic in 2004 , the Slovak Republic amended the original Administrative Procedure Code of 1967 five times.25 Thus, the latter is the predecessor of the existing Czech Administrative Procedure Code.

In respect of the system of regular remedial measures within the administrative procedure, the Slovak Administrative Procedure Code recognizes two or, as the case may be, three remedial measures.26 The first remedial measure is the appeal (Section 53 - odvolanie) and the second is the remonstrance (Section 61 - rozklad). Both of these remedial measures are fully vested in the parties to the procedure.

Both cases represent regular remedial measures for which procedure needs to be conducted by the higher-instance administrative body, although this may be considered as disputable when it comes to the remonstrance since remonstrance contains no devolution effect. The time-limit for their filing is 15 days. Unlike the Polish legislation, the Slovak legislation does not differentiate amongst remedial measures based on whether they are aimed against decisions on the merits or decisions of a procedural nature. Decisions of a procedural nature may be contested by the stated remedial measures unless a special law excludes it. Under specific conditions [Section 57(1)], even auto-remedy is admissible in both cases.

While the appeal is 'the most general regular remedial measure against a decision passed within the administrative procedure'27, the remonstrance, conversely, is aimed against decisions passed by an administrative body with no higherinstance (appellate) administrative body, so no appeal is possible. Concurrently, to ensure the administrative review of a decision passed by such administrative body, the legislation has created the specific institute of remonstrance. Remonstrance is determined by the entity governing such administrative body (usually ministries or other central state administration bodies, with the minister or the head of such body passing a decision) on the proposal of an independent remonstrance commission. 28 However, such proposal is not binding. As stated by the Slovak theory, 'compared to the appeal, it is a special regular remedial measure sought only against decisions passed by these types of administrative bodies'.29 The procedure for remonstrance is subject to the provisions pertaining to an appeal [Section 61(3)]. However, no appeal against such decision may be filed [Section 61(2)] and the matter is determined finally and conclusively at the level of public administration.

The third remedial measure is a measure that is not determined by the administrative bodies but directly by the courts (Section 70). Unfortunately there is no special term for this legal measure; it is described as an ordinary remedy to (administrative) court. But this conception forgets the main distinction between (administrative) justice and public administration as part of executive power. Administrative justice is no continuing of administrative procedure! The competence over this remedial measure is vested in the courts within administrative justice, but only in the cases expressly stipulated by the laws $\underline{30}$. It concerns the procedure for a regular remedial measure in the cases when the superior administrative body is missing, rather than the 'traditional' procedure for an action, through which the final administrative decision is contested. They most frequently concern matters relating to (disability or old age) pension insurance. 31 The time-limit for seeking a remedial measure with the court is 30 days.

In this respect, a question arises as to whether the stated solution may be accepted as possible compensation for the highly disputable institute of remonstrance, by which the solution would be similar to the approach applied in the Hungarian Administrative Procedure Code (see below). But as is noted, such approach also produces a lot of problems and questions. 


\section{Czech Republic and Act No. 500/2004 Coll., on the Administrative Procedure Code}

The Czech Administrative Procedure Code has already been briefly introduced above. From the perspective of the legislation concerned, it regulates regular remedial measures, but does not expressly confirm the principle of a twoinstance procedure as the Polish legislation in Section 15 of KPA. With regard to the explicit legislative absence of the principle of a two-instance administrative procedure, the conclusions of the judicature of the Constitutional Court and the Supreme Administrative Court are not surprising. This judicature recognizes the existence of such principle 32 and directly refers to it, in particular, in cases when it has been violated, but does not ascribe it the nature of a fundamental principle. As expressly stated by the Constitutional Court33, 'neither the Charter of Fundamental Rights and Freedoms nor the Convention for the Protection of Human Rights and Fundamental Freedoms guarantee the fundamental right to seek two- or multiple- instance administrative procedure'. In compliance therewith, the Supreme Administrative Court34 concluded that 'the fundamental principles of determining rights and obligations of natural persons or legal entities by administrative bodies shall not include two-instance decision-making'. Therefore, it can be concluded that the administrative procedure and the administrative bodies' decision-making, where the principle of a two-instance procedure does not apply at all or, possibly, does apply but only in certain modified form, are admissible. Hence, the right to seek regular remedial measures is a matter of common laws and is not constitutionally guaranteed.

The system of regular remedial measures consists of the appeal (Section 81 - odvoláni) and the remonstrance (Section 152 - rozklad). 35 As already stated, the existing Slovak Administrative Procedure Code was the predecessor of the Czech Administrative Procedure Code. The solutions to such regular remedial measures are identical, and even the legislations are similar. The institute of remonstrance was also preserved by the Czech Administrative Procedure Code and, thus, its essence is identical with that applicable in the Slovak Republic (see above).

The time-limit for seeking both remedial measures is 15 days. The auto-remedy is admissible too. Quite a significant shift compared Slovak predecessors concept is so called incomplete appellation in appeal proceedings and related concentrations proceedings at first instance [Section 82(4)]. In appeal and remonstrance procedure can't be used evidence and facts that could be used in the first instance level.

The legislation pertaining to both regular remedial measures is fragmented since remonstrance is regulated, due to its specific nature, by other (the third) part of the Administrative Procedure Code, dealing with the institutes applied within the administrative procedure less frequently. However, based on the statistical data, the institute of remonstrance is not as exceptional as it seems. $\underline{36}$

\section{Hungary and administrative procedure code}

Similar to the Czech Administrative Procedure Code, the Hungarian Administrative Procedure Code was adopted in 2004 (for the sake of completeness it has to be pointed out, that in December 2016 a new regulation was passed under the no. CL: 2016 on the General Administrative Ordinance, which will come into life on $1^{\text {st }}$ January 2018) 37 . For this reason - at current state - the Hungarian regulation belongs, along with the Czech Administrative Procedure Code, to the group of new Administrative Procedure Codes of V4 countries. 38 This legislation is referred to, in compliance with the Hungarian method of identifying laws, as 'CXL: 2004'.

Pursuant to the provisions (Section 71(1) of CXL: 2004), it is necessary to differentiate between decisions on the merits and decisions of a procedural nature. The type of a decision predetermines the system of remedial measures. A decision of a procedural nature may only be contested separately in the cases stipulated by the CXL: 2004.39

The system of regular remedial measures contained in the Hungarian Administrative Procedure Code is related to the right to seek regular remedial measures, guaranteed by the Constitution (Article XXVIII paragraph 7). 40 The Hungarian Administrative Procedure Code does not explicitly differentiate between regular and extraordinary remedial measures within their systematics, but divides them based on whether they are vested in the addressee of an administrative act (redress procedure) or not (ex officio, review procedure). Generally, the substance of regular remedial measures is the fact that they are vested in the addressee of an administrative decision. Hence, a classical regular remedial measure is the appeal (Section 97(2) and Sections 98 through 108). The time-limit for filing an appeal is 15 days. Alongside this, the Administrative Procedure Code CXL: 2004 counts judicial review (Sections 109 through 111, including the reference to the legislation given by the Hungarian Civil Procedure Code - Act III: 1952) and renewed procedure on the basis of a decision of the Constitutional Court (Section 113 and Act CLI: 2011 on the Constitutional Court) amongst other remedial measures available to the addressee of an administrative act within the renewed procedure (Section 112). 
However, these do not concern regular remedial measures since they are, in part, the extraordinary remedial measures (renewed procedure) and, in part, the elements of the follow-up judicial review and the provided court protection.

The legislation pertaining to the appeal does not differ from the appeal-related legislations of the other V4 states. The possibility of filing an appeal is excluded in specific cases as stipulated by Section 100(1) of 1 CXL: 2004. One of the cases of decisions against which no appeal is admissible is the decision of a minister or an independent administrative body.

Unlike Hungary, the Polish, Slovak and Czech legislations have chosen the possibility of remonstrance. The possible Central European 'problem' about the remonstrance is dealt with by the Hungarian Administrative Procedure Code in Section 100(1) d) in favour of the direct judicial review. No matter how the problems associated with the remonstrance are so resolved, the review is delegated directly to the courts, which does not have to be an efficient solution and may lead to the courts being overburdened with these cases.

The construction of Section 97 of CXL: 2004, which regulates all remedial measures, including the possibility of judicial review, is advantageous for the parties to the procedure who so obtain a simple overview of the measures allowing them to exercise their rights. Thus, these parties are notified of what measures may be sought for their rights to be exercised and protected.

\section{Comparative notes and summary}

The individual V4 countries have their own administrative procedure rules. Although these rules can be divided into 'old' and 'new', the common or different elements do not lie in the age of their legislations.

The administrative procedure is always, either fully, such as in case of the Slovak Administrative Procedure Code, or predominantly, such as in case of the other Administrative Procedure Codes, the core of the V4 states' administrative procedure rules. A certain deficiency of the Slovak legislation lies in the fact that it does not pay attention to other forms of administrative bodies' activity and to the procedural regulation of other processes by which the administrative bodies may exercise their competence and participate in the performance of public administration. The Slovak legislation lacks a legal framework for the other forms of public administration activity. The stated narrower scope of applicability of the Slovak Administrative Procedure Code is definitely influenced by the conditions prevalent at the time of its adoption when many public administration procedures (intentionally) remained unregulated by the laws.

Although it is possible to find both decisions on the merits and procedural decisions, the Administrative Procedure Codes of V4 states allow contesting both forms of the decisions through either the same type of a remedial measure (Czech Republic and Slovakia) or a specific category of remedial measures, such as the Polish KPA.

In terms of the understanding and the system of regular remedial measures applied in the administrative procedure, the Administrative Procedure Codes of V4 countries are considerably similar. Except for the Hungarian Administrative Procedure Code, all of them stem, although it often does not expressly ensues from their texts, from the classical division of remedial measures into regular and extraordinary. The division criterion is based on whether the respective remedial measure is aimed against a decision that has already come into legal force or not. Conversely, the Hungarian Administrative Procedure Code divides remedial measures based on whether they are available to the addressee or not. The advantage of this approach is that the party to the procedure is aware of all remedial measures guaranteed by the Administrative Procedure Code and may choose which of them to use. Concurrently, such party must respect their possible sequence or conditionality, which applies, in particular, to the judicial review.

The basic regular remedial measure in V4 states' Administrative Procedure Codes is an 'appeal'. An appeal may be aimed against a decision that has not yet come into legal force and the competence to determine the matter is delegated to the superior body (devolution effect of an appeal). The time-limits for filing it as stipulated by the Administrative Procedure Code are identical in essence (14 or 15 days).

The appeal in the Czech and Slovak environments is also represented by a specific regular remedial measure, being the 'remonstrance'. At present, the remonstrance raises numerous questions. In my opinion, it is an anachronism of the past since it is not desirable and sustainable that the administrative review is carried out solely by the central public administration body. $\underline{41}$

Moreover, the remonstrance-related laws contained in the Czech and Slovak Administrative Procedure Codes are considerably minimalistic since they stem from similar application of appeal-related provisions. Is the remonstrance a special type of the appellate procedure of an internal nature or a regular remedial measure as such? Similar questions and problems can be found even in case of the Polish KPA. Conversely, the Hungarian Administrative Procedure Code copes 
with the whole issue quite clearly since it does not recognize and regulate any institute of remonstrance and, instead, vests the resolution of such matters in the judicial review. However, a question arises as to whether the stated resolution could be considered as possible compensation for the institute of remonstrance. Regarding the institute of remonstrance, its specificity raises numerous theoretical and practical problems in both the Czech Republic and Slovakia.42 As stated above, even the Polish professional literature shows ambiguities. In my opinion, remonstrance clings to the historical concept, which, however, does not suit the conditions and the environment of a legal state of the $21^{\text {st }}$ century.

The Czech Administrative Procedure Code is deviating when it comes to the system and lucidity of its legislation. The first remedial measure ('appeal') is regulated by Section 81, while the second, relatively specific remedial measure ('remonstrance') is regulated in Section 152, that is, far behind the provisions pertaining to extraordinary remedial measures or administrative execution. For this reason, the orientation in the Czech Administrative Procedure Code requires its perfect knowledge. Conversely, the other Administrative Procedure Codes are exemplary as to their systems. The regular remedial measures are specified in a single place in logical sequence. Regarding natural persons and legal entities, the most instructional Administrative Procedure Code is the Hungarian Administrative Procedure Code that provides a list of possible remedial measures, including the follow-up judicial review, in a single place.

It should be noted, that remedial measures are designed to participants of administrative procedures to protect their rights and freedoms. This is from the external scope of view. But there is also strong scope of internal consequences. The 'appeal' is therefore regarded as an instrument of internal or hierarchical control of Public Administration. Thanks appeal starts the function of superior administrative body. There is a large choice of different results that can be used by superior administrative body. The most typical is the cancellation according to the cassation principle. To this we should add that the use of remedial measure represents also one condition for damages caused by 'wrong and unlawful' administrative decision. It can be concluded that regular remedial measures have several functions.

The legislations on regular remedial measures in V4 states' Administrative Procedure Codes are very similar, also due to the influence of the Europeanization requirements. The admissibility of regular remedial measures is recognized generally and only a special law or a special nature of the decision-making administrative body can stipulate otherwise. In all cases, the access to court protection is conditioned by the previous exhaustion of regular remedial measures. Therefore, the possible differences are given, in particular, by the historical development and tradition.

It should be emphasized that even if in different laws could not be found in all V4 countries the existence of the principle of two instances, all V4 countries have similar roots and all of them admits an 'appeal'. Therefore an appeal represents similar and connecting legal remedy of Central European legal culture. It is 'standard' of the legal regulation that can be found. All exceptions should be interpreted restrictive.

Finally, it is worth mentioning that the higher number of remedial measures on its own does not guarantee a higher standard of protection of the rights. It is important to find the suitable balance between identifying remedial measures for addressees of public administration activity and, concurrently, these remedial measures not paralyzing the public administration activity. In principle, one regular remedial measure fully suffices the administrative procedure purposes if it is conceived broadly and can be sought in a wide range of cases. This basic method of protecting rights is represented in all V4 states' Administrative Procedure Codes by the institute of appeal.

\section{References}

1 Compare the institute of objections made in case of selected decisions of the Czech Social Security Administration pursuant to Act No. 88 of Act No. 582/1991 Coll., on the organization and implementation of social security, as amended.

2 As stated on the group's website, the V4 group did not arise as an alternative to the efforts towards pan-European integration and does not try to compete with functional central European structures. In no way shall its activities be aimed against isolating or weakening the relationships with other countries. Instead, the group tries to boost optimal cooperation with all countries, in particular, the neighbouring countries, and is interested in all parts of Europe developing democratically. Compare http://www.visegradgroup.eu/about .

3 Alongside the V4 countries, the administrative procedure rules can be found, for example, in Spain, Croatia, Switzerland, Slovenia, the Netherlands or Iceland. It is definitely not uninteresting that the adoption of such administrative procedure rules is also discussed at the level of the European Union as such (see below). Administrative procedure rules can also be found, for example, in the United States - the federal Administrative Procedure Act (APA) of 1946. 
4 Compare in more detail the German Administrative Procedure Code of 1976, known under the abbreviation VwVfG and being a major inspiration base for other (central) European administrative procedure rules.

5 The first administrative procedure rules in the Czech Republic (and Slovak Republic) were adopted in 1928 (P. Průcha, Správní rád s poznámkami a judikaturou 13 [Administrative Procedure Code with notes and judicature] Leges, Praha, 2012), in Poland in 1928 (Adamiak, B., Borkowski, J., Postepowanie administracyjne I sadowoadministracyjne, 7. wydanie, 54 [Administrative Procedure Law and Administrative Justice Procedure Law, $7^{\text {th }}$ ] editionLexisNexis Polska, Warszawa, 2009) and in Hungary in 1929 (Horáková, M. et al., Správní rízeni v zemich EU [Administrative Procedures of EU Countries], Praha: Linde 2012, p. 237).

6 Compare also Adamiak, B., Borkowski, J., Postepowanie administracyjne I sadowoadministracyjne, 7. wydanie 82-83 [Administrative Procedure Law and Administrative Justice Procedure Law, $7^{\text {th }}$ edition] (LexisNexis Polska, Warszawa, 2009), L. Klat-Wertelecka, (ed), Kodeks postepowania administracyjnego 11 [Code of Administrative Procedure] (ODDK, Gdańsk, 2012), M. Vrabko et al., Správne právo procesné. Vseobecná čast 54 [Administrative Procedure Law. General Part] (C. H. Beck, Bratislava, 2013), S. Košičiarová, Správny proriadok. Komentár, 7 [Administrative Procedure Code, Commentary] (Heuréka, Šamorín, 2013), or P. Váczi, Procedural Principles of Public Administration in Hungary, in P. Smuk, The Transformation of the Hungarian Legal System 2010-2013, 185 (Wolters Kluwer, Budapest, 2013).

$Z$ They are sometimes referred to as administrative bodies directly by the laws since they constitute a legal concept. Section 1(1) of the Czech Administrative Procedure Code contains the general list of bodies considered as 'administrative'. The Slovak Administrative Procedure Code defines 'administrative bodies' in Section 1(2). The Hungarian Administrative Procedure Code contains a more specific definition of administrative bodies in Section 12(3) introducing the term 'authority' or 'administrative authority'. The Polish Procedure Code refers to 'public administration bodies' in Section 5(2).

$\underline{8}$ Thus, the provisions that are the subjects of regulation by the Administrative Procedure Codes are very important since they constitute the procedural basis of administrative activity and co-create the contents of administrative law, as these contents are defined by the German speaking theory as 'Recht der Verwaltung' (compare B. Raschauer, Allgemeines Verwaltungsrecht. $2^{\text {nd }}$ updated edition. 4 [Springer, Wien, 2003]). In terms of the administrative procedure rules, it is definitely not uninteresting that a relatively isolated sub-sphere - being the Administrative Procedure Law - is established within the Administrative Law alone as a scientific and pedagogical discipline. This is obvious the most in the Czech and Slovak Republics. The Administrative Procedure Law pays attention to the procedures carried out by administrative bodies and to the administrative procedure rules. The same is confirmed by the professional literature focused on the Administrative Procedure Law. Compare S. Skulová, et al., Správní právo procesní, 2. upravené vydání [Administrative Procedure Law], $2^{\text {nd }}$ updated edition. (Aleš Čeněk, Plzeň, 2012), or M. Vrabko et al., Správne právo procesné. Všeobecná čast [Administrative Procedure Law. General Part]. (C. H. Beck, Bratislava, 2013).

2 In this respect, it is necessary to mention that compared to civil procedure rules, administrative procedure rules are usually briefer and less complicated. The reason for this is the much higher probability of natural persons and legal entities coming into contact with public administration rather than with the court and the fact that public administration is often performed by officers without legal education. Hence, administrative procedure rules must be understandable.

10 Compare S. Skulová et al., Správní právo procesní, 2. upravené vydání, 10 [Administrative Procedure Law, $2^{\text {nd }}$ edition] (Aleš Čeněk, Plzeň, 2012).

11 In case of the Slovak Administrative Procedure Code, it needs to be stated that administrative procedure represents the core of its legislation. It focuses on other procedures usually available within the public administration only marginally and indirectly. Pursuant to Section 3(7) of the same Code, 'provisions pertaining to the basic procedural rules stated in paragraphs 1 through 6 shall reasonably apply also to the issue of certificates, opinions, statements, recommendations and other similar measures'. The Slovak Administrative Procedure Code also regulates the administrative procedure through all its 85 Sections. On the contrary, the Polish Administrative Procedure Code regulates not only the administrative procedure but, as stated in Section 1 thereof, also the issue of certificates (Part Seven, Section 217 et seq.) and the filing and handling of public administration-related complaints (Part Eight, Section 221 et seq.). In terms of the scope of applicability, it is appropriate to add that the Czech Administrative Procedure Code regulates, primarily, the administrative procedure. This legislation forms a crucial part of the Administrative Procedure Code and is included in its Parts Two and Three, that is, in Sections 9 through 153, while Part Four is devoted to 
regulating the so-called other acts, such as opinions, statements, certificates or standpoints. Part Five of the same Code regulates public contracts. Part Six regulates a specific institute, being measure of a general nature, and Part Seven deals with the issue of public administration-related complaints. The Hungarian Administrative Procedure Code also focuses on procedures other than administrative as stipulated in Section 12 thereof.

12 With the exception stated in the footnote No. 12

13 Pursuant to Section 9 of the Czech Administrative Code, 'administrative procedure is a procedure which shall be carried out by an administrative body and the purpose of which shall be to pass a decision establishing, changing or cancelling the respective party's rights and obligations and declaring that such party shall or shall not have such rights or obligations'. Section 1(1) of the Slovak Administrative Procedure Code defines the administrative procedure by stipulating that 'this Code shall apply to the procedure within which the administrative bodies decide on the rights, the legally protected interests and the obligations of natural persons and legal entities in the sphere of public administration unless a special law stipulates otherwise'. The Polish Administrative Procedure Code, as well as the Czech and Hungarian Administrative Procedure Codes, does not focus predominantly and solely on the administrative procedure but also on other procedures available within the public administration. Section 1(1) of the Polish Administrative Procedure Code defines the administrative procedure as 'a procedure conducted by, and falling within the competence of, public administration bodies resolving individual matters by way of administrative decision'. The Hungarian Administrative Procedure Code defines the administrative procedure in Section 12(2) a) as 'a procedure within which an administrative body defines client-related rights or obligations...'.

14 For the definition in the Czech theory of administrative (procedural) law compare S. Skulová, et al., Správní právo procesni, 2. upravené vydání, 241 [Administrative Procedure Law, $2^{\text {nd }}$ amended edition] (Aleš Čeněk, Plzeň, 2012); for the Slovak concept of regular remedial measures compare M. Vrabko, et al., Správne právo procesné. Všeobecná čast', 177 [Administrative Procedure Law. General Part] (C. H. Beck, Bratislava, 2012); the Polish definition of regular remedial measures is contained in B. Adamiak, J. Borkowski, Postepowanie administracyjne I sadowoadministracyjne, 7. wydanie, 258 [Administrative Procedure Law and Administrative Justice Procedure Law, $7^{\text {th }}$ edition] (LexisNexis Polska, Warszawa, 2009); and for the Hungarian concept of (regular) remedial measures compare K. Pollák, Achievement of the Right to Legal Remedy in the Hungarian Administrative Procedure, 122 in Control of the Decision-making Processes in Public Administration as a Means of Economic Efficiency of Public Administration, Compendium of Contributions from the International Scientific Conference 'Bratislava Legal Forum 2013' Komenský University in Bratislava, Bratislava.

15 Compare, for example, Article V of the Amendment to Resolution 77/31 concerning the protection of individuals in relation to administrative bodies' acts, according to which the decision needs to state what remedial measures can be applied against the respective individual. The possibility of administrative review is stipulated in Article IV paragraph 9 of Recommendation 80/2 on the exercise of administrative discretion. Article VIII of the Amendment to Recommendation $81 / 19$ on access to information held by public authorities also states the requirement for the review of decisions. Article VI of the Amendment to Recommendation 87/16 on administrative procedures relating to a large number of persons stipulates that information on the regular remedial measures should be given. A crucial article is Article 18 paragraph 2 of the Code of Good Public Administration [Amendment to Recommendation 2007/7 on good public administration], pursuant to which a decision must contain a notice of admissibility of regular remedial measures.

16 Article 2 b) of the Principles of Recommendations 2004/20 on the judicial review of administrative acts stipulates that before the court protection and the judicial review of an administrative act is implemented, it is possible to require that all remedial measures available within the procedure conducted by an administrative body are exhausted. This is confirmed by Article 22(2) of the Code of Good Public Administration [Amendment to Recommendation 2007/7 on good public administration], pursuant to which an appeal may be filed within the administrative procedure before the review is carried out by the court; such appeals may even be mandatory in certain cases.

17 For the issue of direct and indirect Union administration further compare, for example, H. C. H. Hofmann, A. H. Türk, EU Administrative Governance (Edward Edgar Publishing, 2006).

18 For this issue compare P. Craig, EU Administrative Law. $2^{\text {nd }}$ edition. 140 et seq. (Oxford University Press, Oxford, 2012), D. Gerardin, R. Munoy \& N. Petit (eds.), Regulation Through Agencies: A New Paradigm of European Governance (Edward Elgar, Cheltenham, 2005), M. Pollack, The Engine of European Integration: Delegation, Agency and Agenda Setting in the EU (Oxford University Press, Oxford, 2003); T. Zwart, L. Verhey (eds.), Agencies in European and Comparative Law (Intersentia, Antwerp, 2003), or W. Weiss, Agencies versus Networks: from division to convergence in 
the administrative governance in the EU, 222-249 in H. C. H. Hofmann, R. L. Weaver (eds.), Transatlantic Perspective on Administrative Law (Bruylant, Bruxelles, 2011). 10.1093/0199251177.001.0001

19 Compare the Resolution of the European Parliament of 15 January 2013, containing a recommendation for the Commission relating to the EU law. The recommendation expressly states that 'Union has no uniform and comprehensive set of codified administrative law rules ...' This document then specifically states recommendation 4.10 relating to the issue of remedial measures. According to such document, 'if so stipulated by the EU laws, administrative decisions shall clearly stipulate that an appeal may be filed and shall specify the procedure for filing such appeal ...' Thus, the stated provisions show that the European Union counts on the possibility of seeking regular remedial measures against decisions of EU bodies and institutions at the level of the EU administrative governance. However, it is not yet unambiguously resolved whether the right to file an appeal is to be incorporated directly in the EU administrative procedure rules or whether the admissibility of its filing is to be regulated by special EU laws. I believe that it would be more appropriate if the EU administrative procedure rules contained the general possibility of filing an appeal against a decision passed by any of the EU bodies or institutions without excluding that special legislation stipulates otherwise in specific cases and contains an exception to this rule. Compare A. Meuwese, Y. Schuurmans \& W. Voemans, Towards a European Administrative Procedure Act. 2 Review of European Administrative Law 3-35 (2009).

20 Compare L. Klat-Wertelecka, (ed.), Kodeks postepowania administracyjnego, 13 [Administrative Procedure Code] (ODDK, Gdańsk, 2012).

21 Compare B. Adamiak, J. Borkowski, Postepowanie administracyjne I sadowoadministracyjne, 7. wydanie, 261-262 [Administrative Procedure Law and Administrative Justice Procedure Law, $7^{\text {th }}$ edition] (LexisNexis Polska, Warszawa, 2009), or A. Skoczylas, M. Swora, Administrative Remedies, 337-338 in Polish Administrative Law. in D. C. Dragos, B. Neamtu (eds), Alternative Dispute Resolution in European Administrative Law (Springer, 2014). 10.1007/978-3-642-34946-1_11

22 Pursuant to Section 188 of KPA, such party may even be the public prosecutor within his control powers towards public administration. Compare B. Adamiak, J. Borkowski, Postepowanie administracyjne I sadowoadministracyjne, 7. wydanie, 266-267 [Administrative Procedure Law and Administrative Justice Procedure Law, $7^{\text {th }}$ edition] (LexisNexis Polska, Warszawa, 2009).

23 Compare in more detail Z. Kmieciak, Wniosek o ponowe rozpatrzenie sprawy w k.p.a. (Odwolanie czy remonstracja?) [Renewed procedure in KPA (Appeal or remonstrance?)] 3 Państvo i prawo (2008), 19-35.

24 Compare A. Skoczylas, M. Swora, Administrative Remedies in Polish Administrative Law, 339 in D. C. Dragos, B. Neamtu (eds), Alternative Dispute Resolution in European Administrative Law (Springer, 2014). 10.1007/978-3-642-34946-1_11

25 J.Sobihrad, Správny poriadok. Komentár, šieste prepracované vydanie, 11 [Administrative Procedure Rules; Commentary, sixth amended edition] (Iura Edition, Wolters Kluwer, Bratislava, 2013).

$\underline{26}$ M. Vrabko et al., Správne právo procesné. Vseeobecná čast', 178 [Administrative Procedure Law. General Part]. (C. H. Beck, Bratislava, 2013).

27 M. Vrabko et al., Správne právo procesné. Vseobecná čast, 178 [Administrative Procedure Law. General Part]. (C. H. Beck, Bratislava, 2013).

28 M. Vrabko et al., Správne právo procesné. Vseobecná čast', 182 et seq. and Section 61(2) [Administrative Procedure Law. General Part]. (C. H. Beck, Bratislava, 2013).

29 M. Vrabko et al., Správne právo procesné. Vseobecná čast', 187 [Administrative Procedure Law. General Part]. (C. H. Beck, Bratislava, 2013).

30 Compare Section 2501(1) of Act No. 99/1963 Coll., the Administrative Procedure Code.

31 The list of cases when a remedial measure may be sought with a court is provided by M. Vrabko et al., Správne právo procesné. Vseobecná čast,' 189 [Administrative Procedure Law. General Part]. (C. H. Beck, Bratislava, 2013), or J. Sobihrad, Správny poriadok. Komentár, šieste prepracované vydanie, 258-261 [Administrative Procedure Rules; Commentary, Sixth amended edition] (Iura Edition, Wolters Kluwer, Bratislava, 2013).

32 Compare, for example, the judgment of the Supreme Administrative Court of 20 July 2004, file number 5 A 69/2001-80, published under number 746/2006 Coll. NSS.

33 See the award of the Constitutional Court of 19 October 2004, file number II US 623/02. 
34 Compare the judgment of 27 October 2005, reference number 2 As 47/2004-61, published under number 1409/2007 Coll. NSS.

35 Compare in more detail S. Kadečka, et al., Dispositional Instruments of Protection against Administrative Acts (not in legal force) and Their Effectiveness, 2-3 International Public Administration Review (2014) 99-122. 10.17573/ipar.2014.2-3.a06

36 The statistical data, though not fully complete, is available in the contribution by S. Skulová, et al., Remonstrance against Decision made by Central Administrative Bodies in the Czech Republic, 2-3 International Public Administration Review (2014) 123-142. It ensues from such data that in the period between 2007 and 2012, remonstrance was the subject of determination in at least 1,200 cases. 10.17573/ipar.2014.2-3.a07

$37 \quad$ See: $\quad<$ http://www.parlament.hu/folyamatban-levo-torvenyjavaslatok? p auth=eFbIRp6a\&p $p$ id=pairproxy WAR pairproxyportlet INSTANCE 9xd2Wc9jP4z8\&p p lifecycle=1\&p p st: 1\&p_p_col_count=1\&_pairproxy_WAR_pairproxyportlet_INSTANCE_9xd2Wc9jP4z8_pairAction=\%2Finternet\%2Fc

38 That the Hungarian Administrative Procedure Code is conceived in the spirit of the principle of good governance and client-oriented approach is obvious with reference to the addressee of administrative activity being identified as 'client'.

39 Compare A. Boros, A. Patyi, Administrative Appeals and Other Forms of ADR in Hungary, 288 in D. C. Dragos, B. Neamtu (eds), Alternative Dispute Resolution in European Administrative Law (Springer, 2014). 10.1007/978-3-642-34946-1_10

40 Compare K. Pollák, Achievement of the Right to Legal Remedy in the Hungarian Administrative Procedure, 121-122 in Control of Decision-making Processes in Public Administration as a Means of Economic Efficiency of Public Administration; Compendium of Contributions from the International Conference 'Bratislava Legal Forum 2013' Komenský University in Bratislava, Bratislava.

41 The remonstrance pursuant to the Czech and Slovak legislations comes into play even in the situations when directly a minister or the person leading the central administrative body has passed the first-instance decision and the remonstrance is determined by the same leader again, but on the proposal of the remonstrance commission. Unfortunately, the leader is not bound by the remonstrance commission's proposal and appoints the remonstrance commission. The details regarding the problematic nature of the remonstrance are stated in the contribution by $S$. Skulová et al., Remonstrance against Decision Made by Central Administrative Bodies in the Czech Republic, 2-3 International Public Administration Review (2014) 123-142.

42 Compare J. Vačok, Možno vždy považovat rozklad za prostriedok nápravy? [Is it always possible to consider remonstrance as a means of remedy?] in Dny práva - 2008 - Days of Laws; the second year of the international conference held by Masaryk University, Faculty of Law, available on $<$ http://www.law.muni.cz/sborniky/dp08/files/pdf/sprava/vacok.pdf $>$. In terms of the Czech legislation compare S. Skulová et al., Remonstrance against Decisions Made by Central Administrative Bodies in the Czech Republic, 2-3 International Public Administration Review (2014) 123-142. 